\title{
繊維化塑性関節法による H 形鋼立体骨組の解析 ANALYSIS OF 3D STEEL FRAMES WITH H-COLUMNS BY A FIBERED PLASTIC HINGE METHOD
}

\author{
島津 勝*, 修行 稔**, 作本裕介*** \\ Masaru SHIMAZU, Minoru SHUGYO and Yusuke SAKUMOTO
}

\begin{abstract}
The adequacy of the fibered plastic hinge model proposed by the authors for the three-dimensional collapse analysis of steel frames with H-columns under strong vertical loads is examined. Also a procedure is presented for evaluation of the strain of the member caused by three-dimensional elastoplastic deformation of a steel frame. The procedure realizes to obtain the strain of a member by a plastic hinge model, not a fiber model. Available test results for one-bay one-story three-dimensional steel frames subjected to eccentric horizontal load under a strong constant vertical load are used to examine the accuracy of the model.
\end{abstract}

Keywords: $H$-column, $3 D$ frame, torsion, collapse analysis, strain evaluation $\mathrm{H}$ 形鋼柱，立体骨組，站じり，崩壊解析，ひずみ評価

\section{1. 序}

建築骨組は三次元的な構造物であるから，高度な性能設計のた めには三次元的な崩壊举動の把握が必要となる可能性がある。

著者の一人は先に，開断面材・閉断面材・半剛接接合部を有す る鈵骨組の統一的三次元崩液解析のための沉用真直はり要素を提 案した ${ }^{1)}$ 。本解法の主な特色は， modified incremental stiffness $\operatorname{method}^{2)}$ を各ステップで要素の㓮体変位を完全に除去する updated Lagrangian formulation と組合わせ, 大変位弾塑性挙動解 析に拉張したものであること，また要素は plastic hinge model で あるが, plastic hinge 部の塑性変形増分を㵶維に分割した断面に 関する数值積分で求めるため, 各種部材の降伏関数に関するデータ ベースを必要としない点にある。なお，柱はり接合部や部材軸線が 急激に折れ曲がる点では断面のそりは拘束されると仮定している。 この要素は CFT 部材の混在する骨組の解析にも，CFT 部材に負 荷されるねじりモーメントが小さければ適用可能であるとともに 3), 上谷らが示した片持はり一柱の構面内举動限界 ${ }^{4)}$ も検出可能 な精密さを有している ${ }^{5)}$ 。

このように，本要素の信頼性はさまざまな既往の実験や解析と の比較によって検証されてきているが，H 形鋼部材に関してはいま だに十分であるとは言い難い。H 形鋼がはり部材として使われる 際の解析の信頼性については文献 1) および 8) において検証され ているが， $\mathrm{H}$ 形鋼が柱部材として使われ，強い軸力の下で偏心水 平荷重によって二軸回りの曲げモーメントと材軸回りのねじりモー メントを受けながら崩壊する場合，さらに偏心水平荷重の絽返しに よって崩壊する場合の本解析法の安定性や精度については全く検証 されていない。本要素は, 塑性変形を断面に関する数值積分を用い
た Newton-Raphson 法で求めているため, このような複雑な弾塑 性挙動の解析における解法の安定性の検証は極めて重要である。 本報は，大きなねじれ変形を伴って崩壊する $\mathrm{H}$ 形鋼立体骨組の 既往の実験的研究 ${ }^{6)}$ および繰返し偏心水平力を受ける $\mathrm{H}$ 形鋼立体 骨組に関する実験的研究 ${ }^{7)}$ に対応する解析を実施し, 本解法がこ のような問題でも標隻值 ${ }^{1}$ ) である 1 部材 4 要素分割 (部材接合部や 集中荷重載荷点などで区切られた 1 部材を部材長の $1 / 10,1 / 2,9 / 10$ の節点で 4 分割すること) で実用上十分な精度を有することを検証 することを目的としている。また，本要素の定式化に際して導入し た仮定に基づいて部材のひずみを推定し，既往の実験值と比較して 仮定の妥当性を確認する。

\section{2. 解析法の概要と特色}

本解法の要素 ${ }^{1)}$ は plastic hinge model であり，その特徴から 繊維化塑性関節モデルと称している。本論文で扱う $\mathrm{H}$ 形鋼につい ては部材の塑性化に関してサンブナンのねじりによるせん断応力の 影響を無視し，そりモーメントによる軸方向応力の影響を考慮する ため，以下のような仮定のもとに定式化している。

（1）部材は薄肉であり，断面はそり成分を除けば平面を保持す る。

（2）骨組の節点変位は大きいが部材の弾性ひずみは小さい。

(3) 軸力, 二軸曲げモーメントおよびそりモーメントによる軸方 向応力のみが部材の降伏に寄与する。

（4）塑性変形成分は軸力，二軸曲げモーメントおよびそりモーメ ントに対応する 4 成分である。

(5) 局部座屈はない。
* 長崎大学丁学部構造工学科 助手·博士 (工学)

** 長崎大学上学部構造工学科 教授. 工博

*** 長崎大学大学院生産科学研究科 博士課程
Research Assoc., Dept. of Structural Eng., Nagasaki Univ., Dr. Eng. Prof., Dept. of Structural Eng., Faculty of Eng., Nagasaki Univ., Dr. Eng. Graduate Student, Graduate School of Science and Technology, Nagasaki Univ. 
（6）要素内では一般化塑性ひずみは線形に分布する。

(7) 要素の長さの半分に生じる塑性変形成分はそれぞれ要素両端 $\mathrm{i}, \mathrm{j}$ の長さ零の plastic hingeに集中して生じる。

\section{1 幾何学的非線形剛性}

要素の両端を $\mathrm{i}, \mathrm{j}$ として $\mathrm{i}$ 端の図心に原点 $\mathrm{O}$ をとり，材軸方 向に $\mathrm{x}$ 軸, これと右手系をなすように断面主軸方向に $\mathrm{y}, \mathrm{z}$ 軸をと る。同様に，i 端のせん断中心 $\mathrm{S}$ に原点をとり，材軸方向に $\overline{\mathrm{x}}$ 軸， これと右手系をなすように断面主軸方向に平行に $\overline{\mathrm{y}}, \overline{\mathrm{z}}$ 軸をとる。 仮定 (1) (2) および modified incremental stiffness method に よって (1) 式を満足する弾性接線剛性行列 $\boldsymbol{K}^{e}$ が得られる。

$$
d \boldsymbol{Q}+\boldsymbol{R}=\boldsymbol{K}^{e} d \boldsymbol{q}^{e}
$$

ここに, $\boldsymbol{R}$ は不平衡力, $\boldsymbol{Q}$ と $\boldsymbol{q}^{\epsilon}$ はそれぞれ 14 成分からなる要 素端力と要素端弹性変位である。 $\boldsymbol{Q}$ と $\boldsymbol{q}^{e}$ の成分は以下のようで ある。

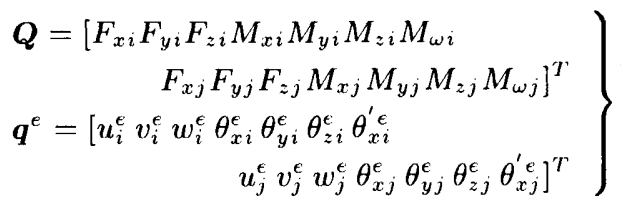

ここに, $F_{k l}$ は $l$ 端の $k$ 力向の力, $M_{k l}$ は $l$ 端の $k$ 軸回りのモ一 メント， $M_{\omega l}$ は $l$ 端のそりモーメントであり， $\boldsymbol{q}^{e}$ の成分は対态す る弾性変位である。各ステッブにおける要素の新しい坐標系とその 座標系での要素端全変位は，回転行列 ${ }^{11)}$ を用いて㴊体変位を完全. に除去して決定し，評価される。従って， $\boldsymbol{K}^{e}$ に含まれる要素端変 位のうちのいくつかは，もし要萦が弾性域にあれば，常に以下のよ うになる。

$$
\left.\begin{array}{l}
u_{i}^{\epsilon}=v_{i}^{\epsilon}=w_{i}^{e}=v_{j}^{e}=w_{j}^{e}=0 \\
\theta_{x i}^{e}=-\theta_{x j}^{e}
\end{array}\right\}
$$

\section{2 塑性变形増分の評価}

plastic hinge に生じる塑性変形增分は，要素出端断面の塑性接 線係数行列を利用して評価する。この係数行列は, 要絫両端の微小 な繊維の，その時点での剛性を断面に関して数值積分することに よって求められる。 $\mathrm{H}$ 形鋼部材においてはサンブナンのねじりに よるせん断応力の影響を考慮しないので，繊維の忍力増分とひずみ 增分の関係は次式で得られる。

$$
d \sigma=E_{t} d \varepsilon
$$

ここに， $\sigma$ は軸力，曲げモーメントおよびそりモーメントによって 生じる垂直応力, $E_{t}$ は䋐維の一軸応力增分〜ひずみ増分関係の比 例係数であり，弾性域ではヤング係数 $E ，$ 降伏後はひずみ硬化係数 $H$ となる。

さて, $\mathrm{H}$ 形鐥部材の一般化志力 $\boldsymbol{f}$, 一般化ひずみ $\boldsymbol{\delta}$ の成分は次 のようである。

$$
\left.\begin{array}{rl}
\boldsymbol{f} & =\left[\begin{array}{llll}
f_{x} & m_{y} & m_{z} & m_{\omega}
\end{array}\right]^{T} \\
\boldsymbol{\delta} & =\left[\begin{array}{llll}
\varepsilon_{0} & \phi_{y} & \phi_{z} & \phi_{\omega}
\end{array}\right]^{T}
\end{array}\right\}
$$

ここに, $f_{x}$ は軸力, $m_{y}$ と $m_{z}$ は曲げモーメント, $m_{\omega}$ はそりモーメ ント， $\boldsymbol{\delta}$ の成分はそれぞれに対応する一般化ひずみである。 plastic hinge 部の断面を微小な繊維に分割し, 繊維の応力と一般化応力の 関係および䋐維のひずみと一般化ひずみの関係を用いて NewtonRaphson 法を適用すれば，一般化応力増分と一般化ひずみ増分の 間に次のような関係が得られる ${ }^{1)}$ 。

$$
d \boldsymbol{f}=\boldsymbol{s} d \boldsymbol{\delta}
$$

ここに，s は断面に関する接線係数行列である。 $\boldsymbol{s}$ を変形すること によって，次式を満足する塑性接線係数行列 $\hat{\boldsymbol{s}}$ が求められる。

$$
d \boldsymbol{\delta}^{p}=\hat{\boldsymbol{s}} d \boldsymbol{f}
$$

ここに， $d \delta^{p}$ は一般化ひずみ增分の塑性成分である。

ここで，H 形鋼部材の要素両端の plastic hinge に生じる塑性 変形增分を次のように定義する。

$$
\left.\begin{array}{rl}
d \boldsymbol{q}_{i}^{p} & =\left[\begin{array}{lllllll}
d u_{i}^{p} & 0 & 0 & 0 & d \theta_{y i}^{p} & d \theta_{z i}^{p} & d \theta_{x i}^{\prime p}
\end{array}\right]^{T} \\
d \boldsymbol{q}_{j}^{p} & =\left[\begin{array}{lllllll}
d u_{j}^{p} & 0 & 0 & 0 & d \theta_{y j}^{p} & d \theta_{z j}^{p} & d \theta_{x j}^{\prime p}
\end{array}\right]^{T}
\end{array}\right\}
$$

これらの塑性変形增分は，要秦の一般化塑性ひずみ增分によって生 じるものである。要秦屾端の塑性接線係数行列 $\hat{\boldsymbol{s}}$ を利用し，仮定 (6)〜(7) を導入すれば，要素活端の塑性変形増分 $d \boldsymbol{q}^{p}$ と要素端力 增分 $d Q$ とを関係づける行列 $\boldsymbol{s}^{p}$ を得ることができる。

$$
d \boldsymbol{q}^{p}=\boldsymbol{s}^{p} d \boldsymbol{Q}
$$

\section{3 弾塑性接線剛性行列}

部材端変位增分 $d \boldsymbol{q}$ が, 弹性変位增分 $d \boldsymbol{q}^{e}$ と plastic hinge に 生じる塑性変形增分 $d \boldsymbol{q}^{p}$ の合計として生じると仮定すると，(10) 式に示寸弹塑性接線剛性行列 $\boldsymbol{K}^{p}$ が得られる。

$$
d \boldsymbol{Q}+\boldsymbol{R}=\left[\boldsymbol{I}+\boldsymbol{K}^{e} \boldsymbol{s}^{p}\right]^{-1} \boldsymbol{K}^{e} d \boldsymbol{q} \equiv \boldsymbol{K}^{p} d \boldsymbol{q}
$$

ここに，Iは単位行列， $\boldsymbol{R}$ は不平衡力である。

\section{4 本解法の特色}

以下に本解析法の特色と思われるところを列举する。

（1）基本的には塑性関節法であり，要素の弾塑性接線剛性行列を 導くのに必要な弾性非線形風性行列は陽な形で得られるの で，解析手順は比較的簡素であり，計算時間を短くできる。

(2) plastic hinge 部の塑性変形增分を，hinge 部を䋐維化して 数值積分で求めるため, 閉断面材と開断面材を統一して扱え るほか，各種の断面の一般化忍力を引数とする降伏曲面の データベースを必要とせず，原理的には任意の断面形状・寸 法や使用材料（一軸応力下での力学的举動が知られているこ とが前提であるが）に対応できる。

(3) 部材と部材の接合部が完全な剛接合でない場合, 接合部の曲 げモーメント〜相対回転角の関係が分かれば，これを要素端 コンプライアンスとして解析に導入できる。接合がピンで あってもコンプライアンスを無限大に近く設定することで解 析が可能であり，态用範网が広い ${ }^{8)}$ 。 
（4）回転行列 ${ }^{11)}$ を用いて, 三次元的に大きな変位を生じる要 素の赛質の変形成分を分離しているので，この実質の変形 成分と要素の現在の位置と向きの情報をもとに，骨組全体 の弾性ひずみエネルギの勾配として内力が評価できる。従っ て，大変位状態における不平衡力（内力と外力増分の総和と の差）が精度よく得られ, modified incremental stiffness method の使用によって釣り合い経路に自動的に引き戻す 機能を有している。

(5) modified incremental stiffness method は, 1 ステップで の変位增分を小さく抑えることを前提に，1 ステップに 1 回づつ不平衡力を打ち消す解法であり，弾塑性域において iteration を行わないので, 大変位弾塑性解析に際して安定 度が高い。

（6）本解法では要素両端の plastic hinge 部を䋐維に分割するた め, 節点を設ければその断面の繊維のひずみを得ることがで きる。本解法では, いわゆる fiber model と異なり plastic hinge 部断面のみを繊維に分割すること，加えてこの plastic hinge 断面に関しては Newton-Raphson 法を用いて高い 精度で一般化応力〜一般化ひずみ関係を追跡していくことか ら, 繊維への分割数は fiber model ${ }^{9-10)}$ に比較するとかな り多くなるが，その分䋐維のひずみ值の精度は高い。本研究 で用いた $\mathrm{H}$ 形鋼の繊維への分割図を図 1 に示す。

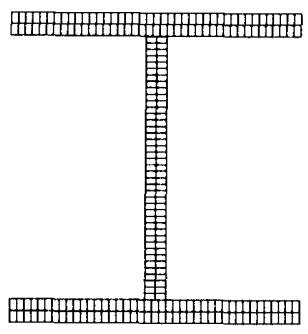

図 1 断面分割図

\section{3. 要素の任意点における絓維のひずみの推定}

前述のように, 本解法では部材の希望する点に節点を設ければ, その断面の任意の場所の緘維の忘力ひずみ履歴を得ることができ る。一方，仮定 (6) から要素内の一般化塑性ひずみ分布は線形であ り，一般化弾性ひずみ分布も線形であるから両者の和もまた線形分 布となる。よく知られているように一般化ひずみと部材繊維のひず みは比例するので，繊維のひずみ分布もまた要素内で線形となる。 従って,

(1) 繊維のひずみが必要な箇所の要素番号と i 端からの距離を調 ベる。

(2) その要素の該当する繊維の $\mathrm{i}, \mathrm{j}$ 両端のひずみの值から比例 配分的に目的のひずみ值を得る。

という手順でひずみの推定が可能となる。後述する解析結果は，こ の方法で推定したものである。

\section{4. 既往の実験との比較}

\section{1 藤本ら $^{6)}$ の実験}

部材ひずみが計測され公表された貴重な実験として藤本ら ${ }^{6)} の$ 立体骨組がある。まずこれを取りあげる。

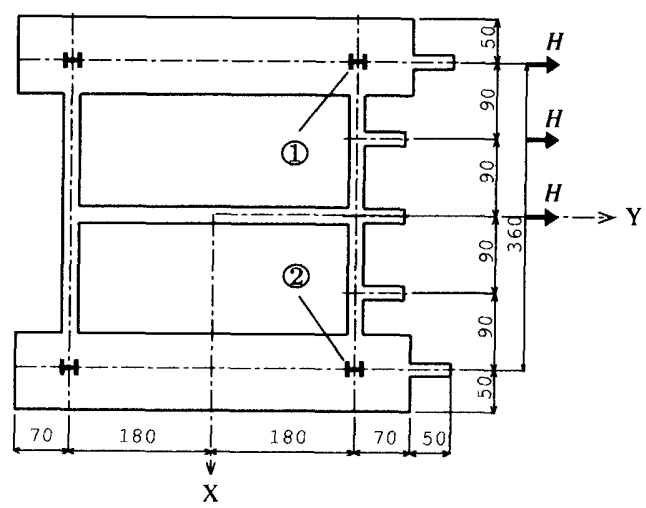

【平面図】

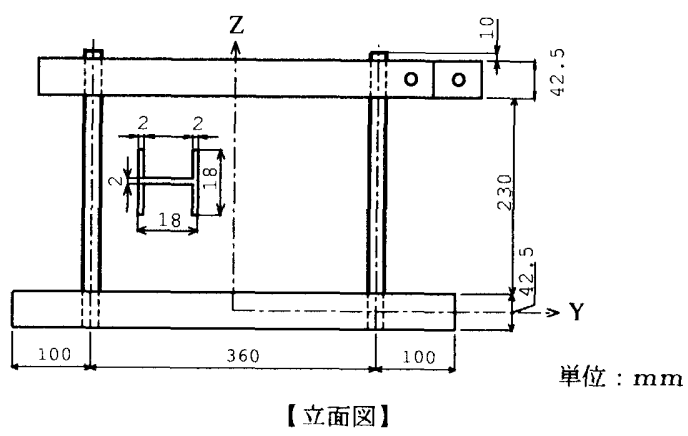

図 2 藤本ら $^{6)}$ の立体鋼骨組

\section{1. 1 骨組の概要}

試験体の概要を図 2 に示す。試験体は X, Y 方向共に 1 層 1 ス パンであり，部材は材質 SS400の軟鋼材から図中に示す寸法に削 り出され，焼鈍されている。試験体の柱頭，柱脚部分には $\mathrm{H}$ 形断 面の叫部に鋼片が挿入され，材端固定治具で柱の両側からはさみ， 高力ボルトで固定される。これにより，柱端部の曲げとねじれは完 全に固定されるものとみなされている。柱頭に载荷される鉛直荷重 は重鍾を用いて一定值に保たれ，図中に示す材端固定治具のいずれ かの位置を水平に引張ることにより偏心水平荷重が载荷されてい る。剛心に対する水平荷重の偏心距離 $e$ と試験体のスパンの $1 / 2$ に対する比率を偏心率 $c$ と定義している。

本報での解析対象は, 柱の軸力比 (柱への導入軸力 $P$ と降伏軸 力 $P_{\mathrm{y}}$ の比) が 0.3 および 0.5 の定鉛直荷重の下で偏心率の翼なる 水平荷重を受ける計 6 種類の供試体である (表 1)。なお, いずれの 試験体においても局部座届が生じたという記述はなされていない。

なお，軸力比 0.3 の供試体には柱頭と柱脚にひずみゲージが貼 付されている。一個所につき 4 枚，供試体一体につき計 32 枚のひ ずみゲージが貼付されているが，文献 6 に実験結果が示されている のはゲージ番号 5〜8 および 13〜16 の計 8 枚についてである。図 3 にそれらの貼付位置を示す。フランジ端からひずみグージまでの 距離はいずれも $2.5 \mathrm{~mm}$ である。

\section{1. 2 解析結果と実験結果の比較}

解析に必要な材料定数は, 藤本らが解析で用いた值と同じく, ヤング係数 $E=206.0 \mathrm{GPa}$, せん断弾性係数 $G=79.4 \mathrm{GPa}$, 降 伏忍力 $\sigma_{\mathrm{y}}=239.0 \mathrm{MPa}$ とした。降伏後のひずみ硬化係数 $H$ は $H=E / 100$ と仮定している。 


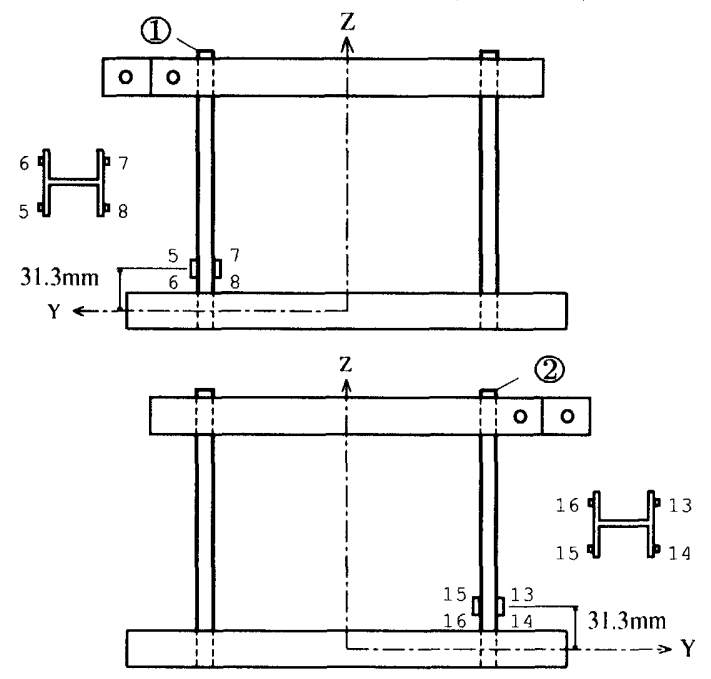

図 3 ひずみゲージ貼付位置

表 1 各供試体の偏心率と柱降伏軸力比

\begin{tabular}{|c|c|c|}
\hline 供試体番号 & 偏心率 $\mathrm{c}$ & 柱降伏軸 万 比 $P / P_{\mathrm{y}}$ \\
\hline $\mathrm{SF}-4$ & 0 & 0.3 \\
\hline $\mathrm{SF}-5$ & 0.5 & 0.3 \\
\hline $\mathrm{SF}-6$ & 1.0 & 0.3 \\
\hline $\mathrm{SF}-7$ & 0 & 0.5 \\
\hline $\mathrm{SF}-8$ & 0.5 & 0.5 \\
\hline $\mathrm{SF}-9$ & 1.0 & 0.5 \\
\hline
\end{tabular}

実験は，屋根面と休面は面内，面外ともに笎全㴊とみなして尖施 されているが，屋根面も床面も鋼材であり，解析において柱脚の煳 定点および屋根面の剛接点をどこに設定するのが妥当であるか㤝必 ずしも明確ではない。本研究では，屋根面床面ともに板垾の中心位 置で固定あるいは剛接されると仮定し，階高を供試体の柱頭と柱脚 の固定治具の中心間距離をとって $273 \mathrm{~mm}$ とした。前述のように， 柱を長さの $1 / 10,1 / 2,9 / 10$ の点で 4 要素に分割し，柱頭の固定治 具は風性の高いはりで置換した。柱の要素両端断面の繊維への分割 数は 246 である(図 1)。

図 4〜6はそれぞれ供試体 SF-4〜6(軸力比 0.3) の剛心における 荷重～加力方向変位, 荷重～直交方向変位, および荷重～ねじれ回 転角の関係である。図 4 以降は原論文 ${ }^{6)}$ に合わせて工学単位系で 描いている。図中の実線が藤本らの実験結果, 破線が本解析による 結果である。本解法の結果は， 3 体とも荷重の低下が実験よりも早 く生じ，荷重と直交方向の変位を大きく見積もっているが，最高荷 重はよく一致している。

図 7〜9 はそれぞれ SF-7〜9(軸力比 0.5) の実験結果と解析結果 の比較である。全体に最高荷重がやや高めではあるが, 本解法の結 果は実験結果をよく表現している。図には金尾 (奥田) ら ${ }^{9)} の$ fiber model による解析結果も示している。本要素は，総合的に見れば fiber model とほぼ同等の精度を有すると言えよう。

なお，藤本らの論文には偏心率 $c=0$ の SF-4 と SF-7 は最大 耐力に達した後, 不安定となって急激に横方向の変位が増大したと の記述があるが，図としては示されていないため本論文ではこの点

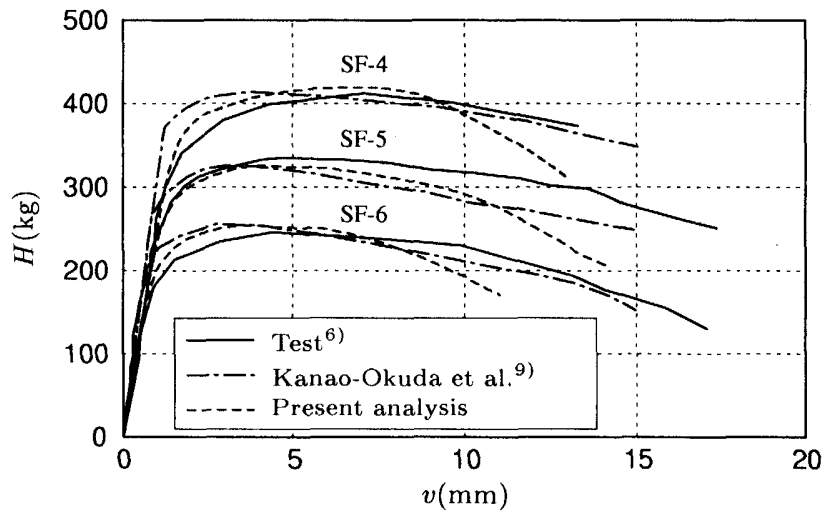

図 4 荷重～加力方向変位関係

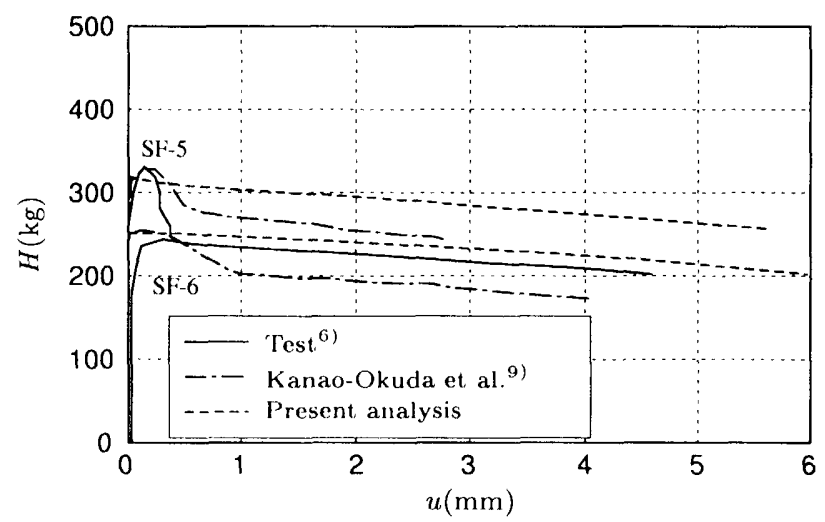

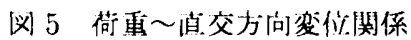

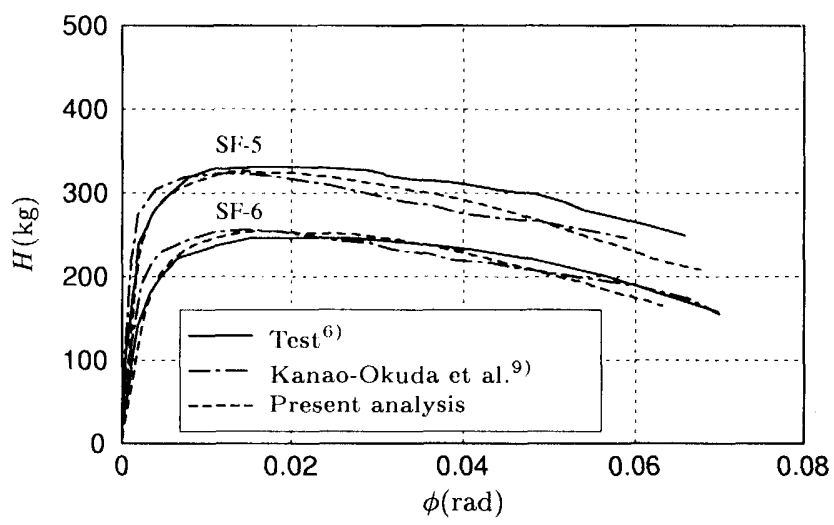

図 6 荷重〜ねじれ回転角関係

についての検討は行っていない。

さて，第 3 節で述べた方法を用いてひずみグージ貼付位置のひ ずみを推定し，実験值と比較してみる。ひずみゲージの貼付位置は， 図 3 に示すように解析モデルで言えば柱の固定端から $31.3 \mathrm{~mm}$ の ところである。一方，解析モデルにおける固定端のすぐ上の節点ま での距離は柱の長さの $1 / 10$ である $27.3 \mathrm{~mm}$ であるから，ひずみ の推定は柱の下から 2 番目の要素の両端の絨維の值を用いて行う ことになる。

図 10(a)〜 (c) はそれぞれ SF-4〜6 の図 2 と図 3 に (1) で示し た柱の,また，図 11 は同じく (2)で示した柱の下端固定部近傍に 


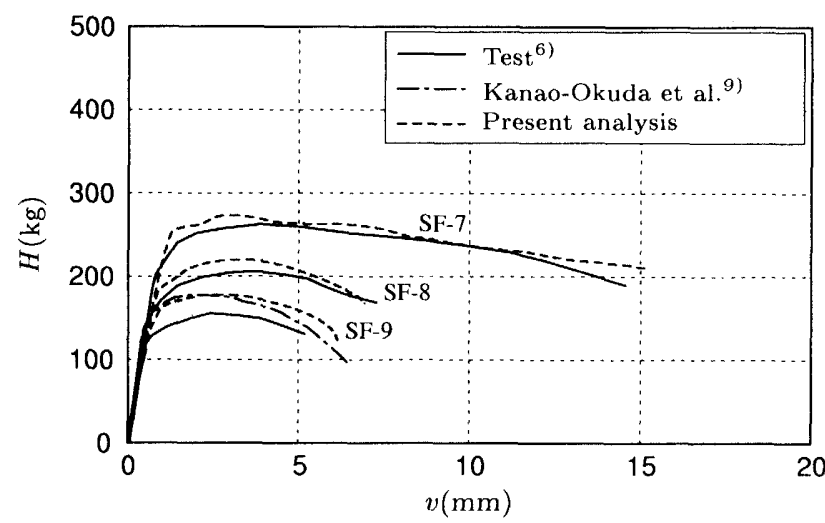

図 7 荷重～加力方向変位関係

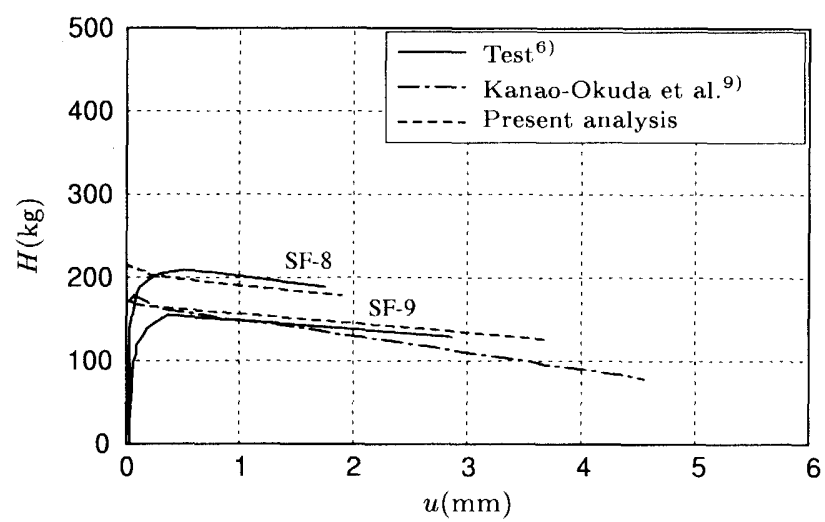

図 8 荷重～直交方向変位関係

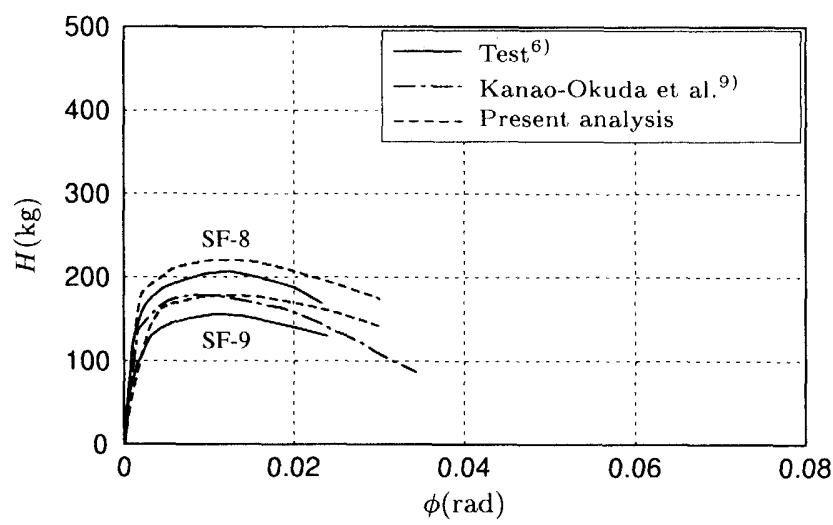

図 9 荷重〜ねじれ回転角関係

おける荷重〜ひずみ関係である。図中の○、

ける藤本らの実験結果, 各種の線で示しているのは本解析の推定值 である。図中の断面図の $\mathrm{x}$ 軸と $\mathrm{y}$ 軸は，それぞれ図 2 と図 3 に示 した全体座標軸 $\mathrm{X}$ 軸， $\mathrm{Y}$ 軸と同じ方向を向いている。

SF-5 と SF-6 の同じフランジ上に貼られた二枚のグージ 5 と 6 および 7 と 8 の值が一致していないが，これは水平荷重によって 骨組がねじられ，柱に二軸回りの曲げと断面のそりが生じているた めである，図 10 の柱 (1)については柱頭の水平力によって生じる 強軸回りの曲げが主体的であり，これに骨組のねじれによる弱軸回 りの曲げの影響が加わっているのに対し，図 11 の柱 (2)について は偏心率が大きいため，骨組のねじれによる弱軸回りの曲げが大き

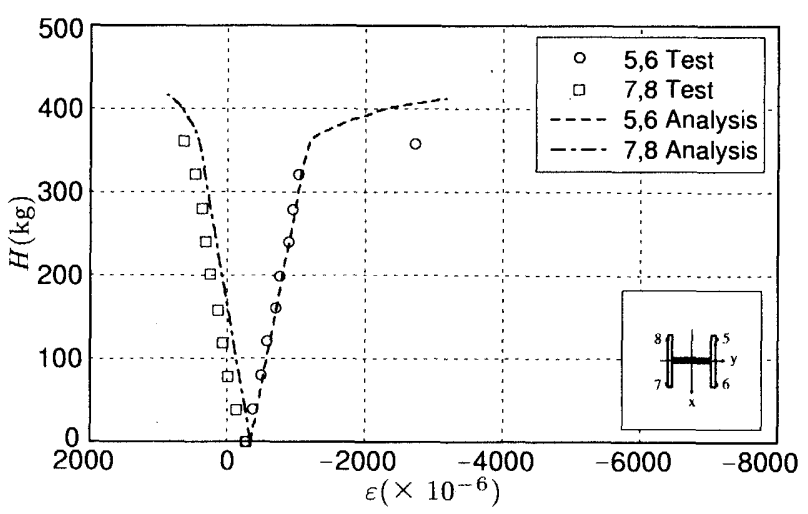

(a) $\mathrm{SF}-4$

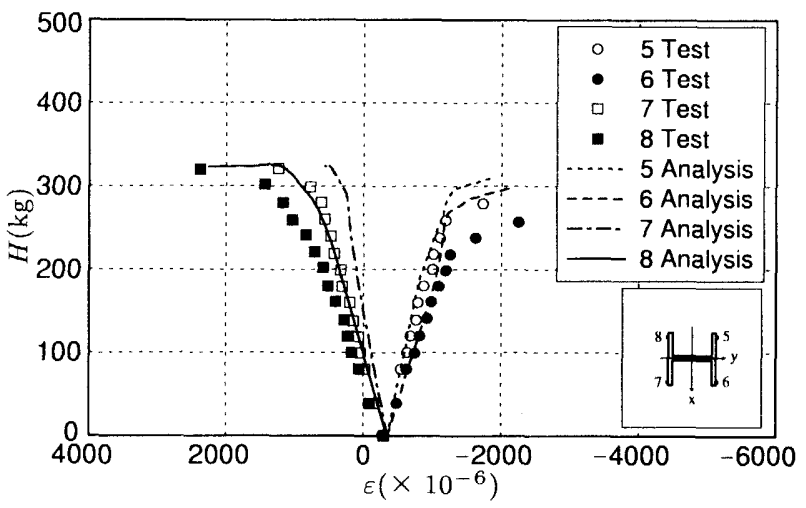

(b) SF-5

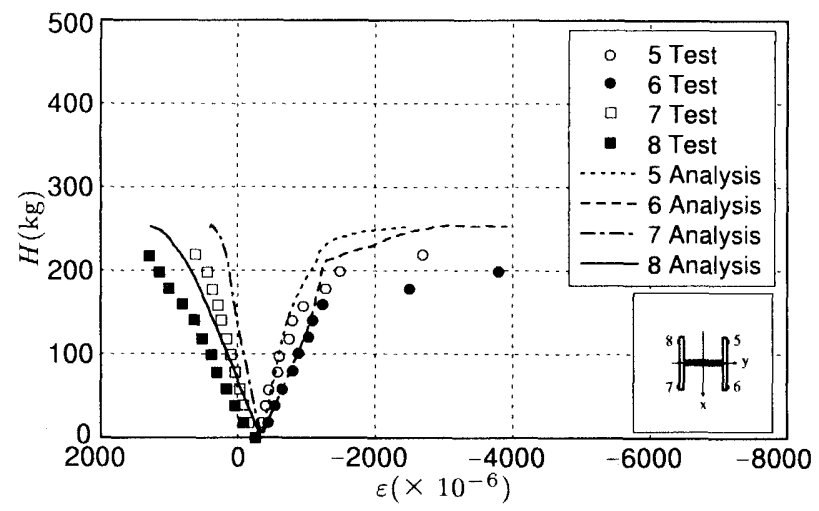

(c) SF-6

四 10 柱 (1) の柱脚部の荷重〜ひずみ関係

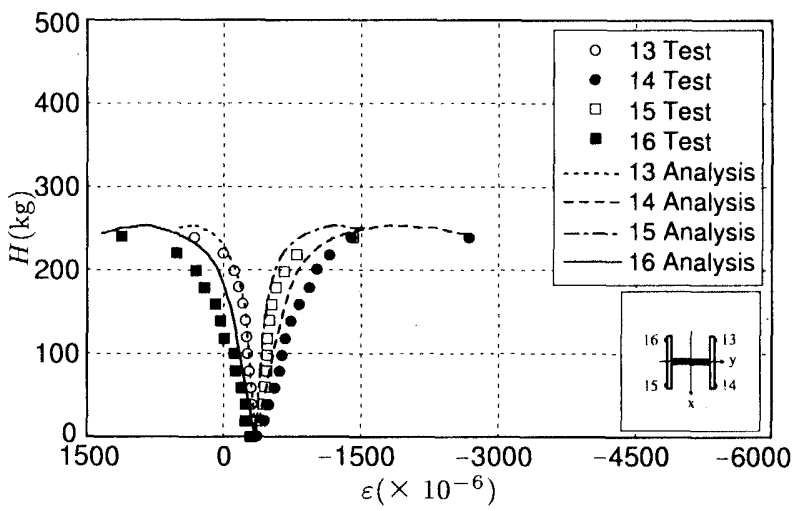

図 11 柱 (2) の柱脚部の荷重〜ひずみ関係 (SF-6) 


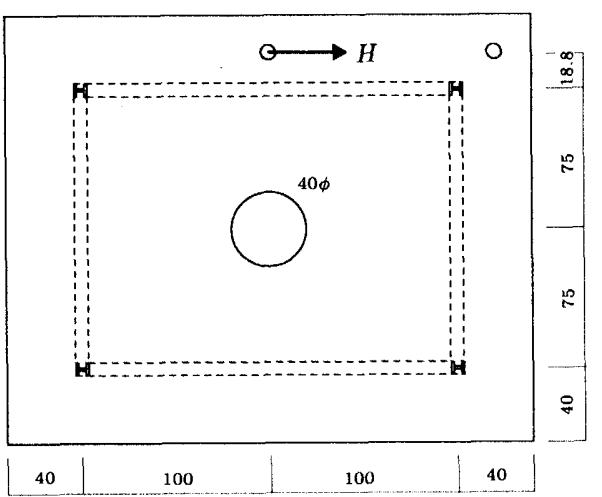

(a) 平面図

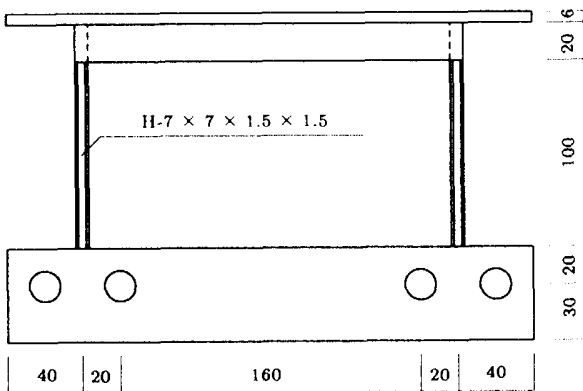

(b) 立面图 1

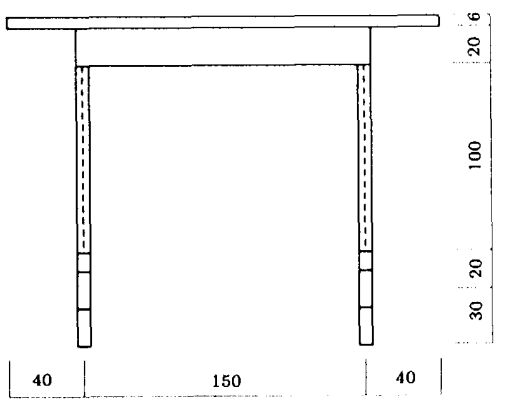

(c) 立面図 2

単位:mm

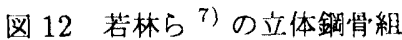

く生じ，これに強軸回りの曲げの影響が加わる形になっている様子 が見てとれる。解析結果もこの現象をよくとらえている。図 10〜 11 は，仮定 (6) の妥当性を示していると見ることができる。なお， 金尾 (奥田)らの論文にはこの荷重〜ひずみ関係の図は示されてい ないため, 本解法の結果のみを示した。

\section{2 若林ら $^{7)}$ の実験}

強い軸力の下で繰返し偏心水平荷重を受ける $\mathrm{H}$ 形鋼立体骨組の 例として若林ら ${ }^{7)}$ が実施した実験との比較を試みる。

\section{2. 1 骨組の概要}

試験体の概要を図 12 に示す。厚さ $10 \mathrm{~mm} の \mathrm{SS} 41$ 鋼板から $\mathrm{H}$ 形断面柱 $(\mathrm{H}-7 \times 7 \times 1.5 \times 1.5) 2$ 本と柱に比して大きな曲げ岡性 を持つ長方形断面はりと基礎ばりを持つ平面骨組 (スパン $200 \mathrm{~mm}$, 階高 $100 \mathrm{~mm}$ ) を機械切削で切り出し，この平面骨組を $150 \mathrm{~mm}$ 間 隔で平行に並べて柱頭部で長方形断面はり 2 本で溶接接合して立 体骨組を作成している。さらに，厚さ $6 \mathrm{~mm}$ の屋根板を柱頭および

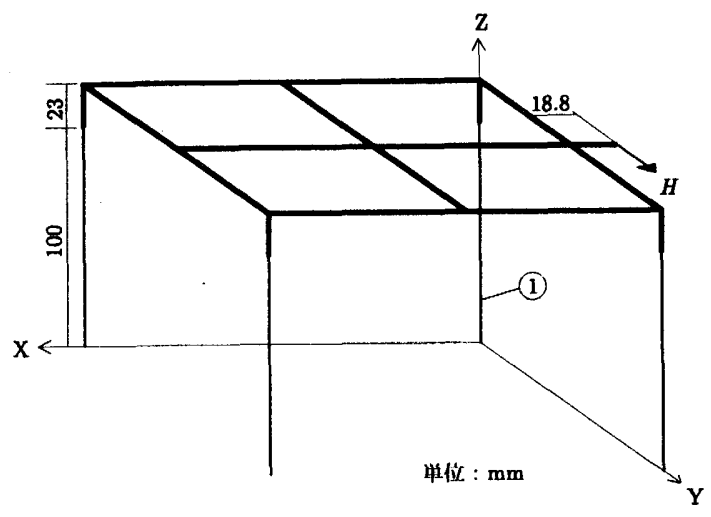

図 13 骨組のモデル化と載荷方法

はりへの断続溶接によって接合している。屋根板には，鉛直力載荷 装置用の径 $40 \mathrm{~mm}$ の孔一つと水平力載荷用の径 $10 \mathrm{~mm}$ の孔二つ が空けてある。基礎ばりは高力ボルトで固定されている。

\section{2.2 解析結果と実験結果の比較}

解析対象は，軸力比 0.332 の鈆直荷重の下で試験体に対して平行に 繰这し载街した PC35 である(困 12(a))。解析に用いた諸量は以ト の通りである。柱の断面の高さ $D=7.01 \mathrm{~mm}$ ，幅 $B=6.91 \mathrm{~mm}$ ， ウェブ厚 $t_{w}=1.50 \mathrm{~mm}$, フランジ倡 $t_{f}=1.38 \mathrm{~mm}$, ヤング係 数 $E=206.0 \mathrm{GPa}$, 女ん断弾性係数 $G=79.4 \mathrm{GPa}$, 降伏志力 $\sigma_{\mathrm{y}}=319.0 \mathrm{MPa}$ ，降伏後のひずみ硬化係数 $H=E / 100$ 。骨組は， その製作状況を考慮して四 13 に示すように柱脚部は固定，柱の長 さ $100 \mathrm{~mm}$ とし，上部の長方形断面はりと屋根板は㓘性の高いはり で䈯換した。その際，水平力载獄点を屋根板の板厚中心と仮定して， 柱の上端と屋相面のはりとの距離を $23 \mathrm{~mm}$ に設定した。㓮性の高 いはりは全て 1 部材 1 要素であるが，柱は爰さの $1 / 10,1 / 2,9 / 10$ の点で 4 要素に分割している。

解析は，屋根面中心位置の Y 方向変位 $(V)$ の除荷点が実験值 と一致するように制御して進めた。原論文の図から読み取った除荷 点の変位は，柱無 $L(100 \mathrm{~mm})$ で無次元化した值で順に，0.0045， $-0.0045,0.0045,-0.0045,0.0099,-0.0099,0.0099,-0.0099$, $0.0197 ，-0.0192 ， 0$ である。繂返し水平力の載荷に祭しては，若 林らの論文にある「現実的な不完全性」を本解析においても導入し， $H$ のみでなく $\mathrm{X}$ 方向荷重 $H_{x}$ を $H: H_{x}=1:-10^{-6}$ の割合で比例 的に載荷した。

図 14〜17 は，それぞれ屋根面中心位置の荷重〜X 方向変位関 係，荷重～回転角関係，荷重〜Y 方向変位関係および中心位置の変 位履歴である。荷重は骨組の Y 方向剛塑性崩壊荷重 $H_{0}$ で, 変位 は柱長 $L$ で無次元化してある。奏験では 6 サイクル目の初めの方 でほぼ崩壊の状態となり実験が中断されている。本解法では 5 少 イクル目の終りの方で塑性接線係数を求める Newton-Raphson 法 の計算が収束しなくなり，図 16 の B 点で解析を中断した。図には 金尾 (奥田) ら ${ }^{9)}$ の fiber modelによる解析結果も示しているが, 本解法の結果は 5 サイクル目の途中までは不確定要因の影響の大き いX 方向変位を除けば fiber modelによる結果とよく一致してお り，本解法は $\mathrm{H}$ 形鋼立体骨組の絽返し載荷に対寸る解析でも安定 で，実用的には十分な精度を有することが確認できたと言えよう。 図 18〜19は，図 13 中に(1)で示した柱の柱脚断面フランジの外 


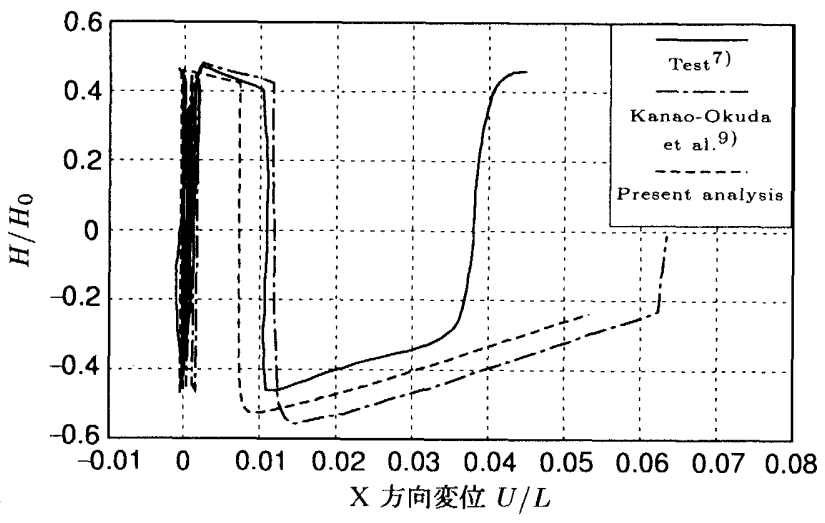

図 14 荷重 $＼textrm{X}$ 方向変位関係

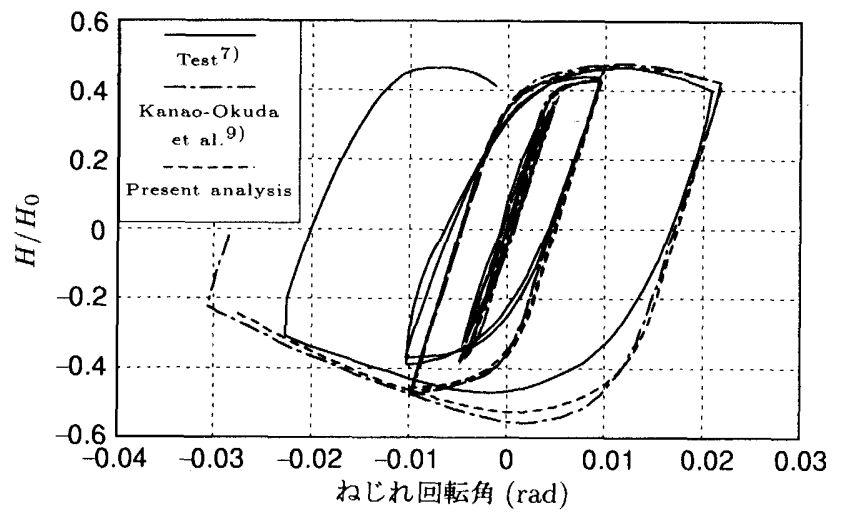

図 15 荷重〜ねじれ回転角関係

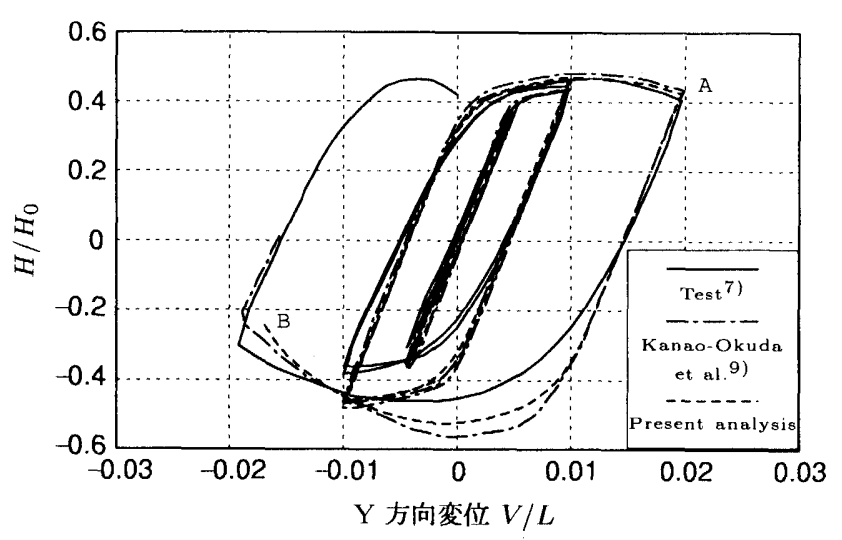

図 16 荷重 $\sim Y$ 方向変位関係

側の繊維の，図 16 に と B で示した時点での応力とひずみの分 布である。いずれも初期降伏応力 $\sigma_{\mathrm{y}}$ と初期降伏ひずみ $\varepsilon_{\mathrm{y}}$ で無次 元化して描いている。 $\varepsilon_{\mathbf{y}}=0.00155$ であるから，B点においては ひずみの大きさが解析では最大で約 0.057 に達していることがわ かる。図 19 のひずみ分布は，定軸力下における繰返し載何による 平均軸ひずみの蓄積，二軸回りの曲げや断面のそりに起因するひず みの総和であり，これらの影響をすべて含んでいる。

図 20 は, 図19に@で示した繊維の忍力ひずみ履歴である。図 中の A 点と B 点はそれぞれ図 16 のそれらに対応している。移動 硬化則にきちんと従っており，極めて安定に解析が進んでいること がわかる。

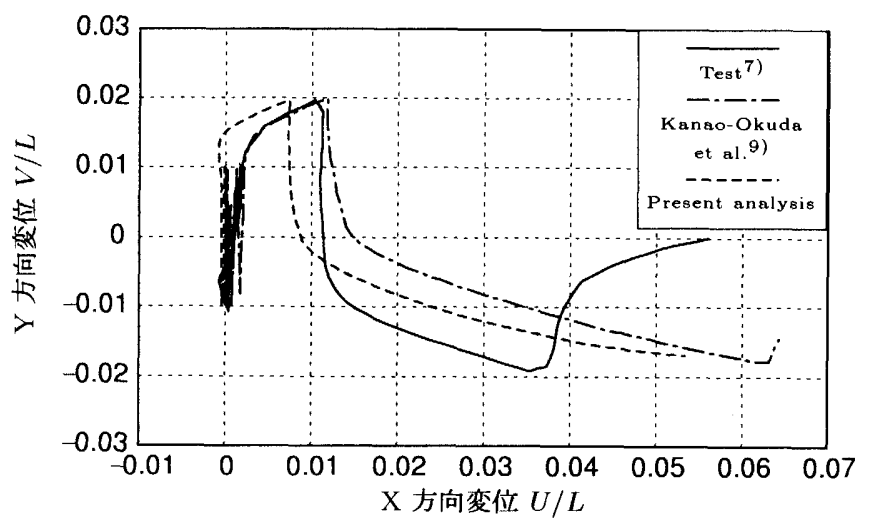

図 17 中心位置の変位履歴
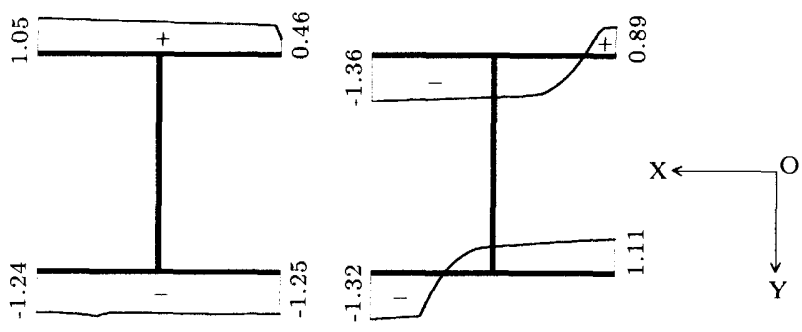
A 点 $(V / L=0.0197)$
B 点 $(V / L=-0.0169)$

困 18 柱(1)の固定端断面の無次元化応力分布

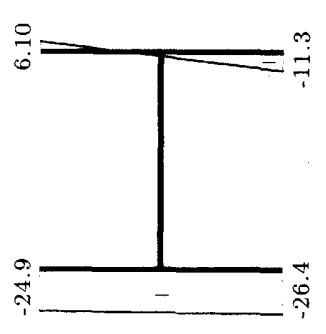

A 点 $(V / L=0.0197)$

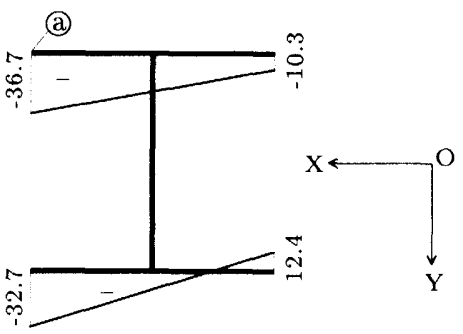

B 点 $(V / L=-0.0169)$
図 19 柱(1)の固定端断面の無次元化ひずみ分布

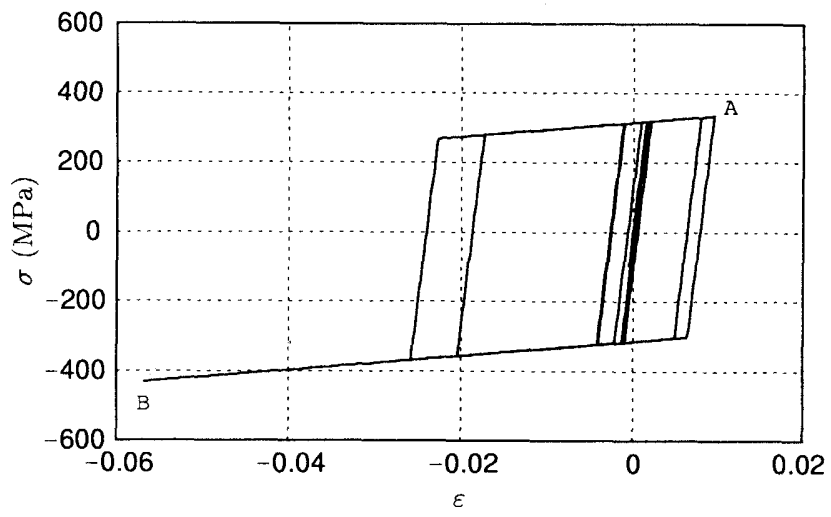

図 20 図19に@で示した瀻維の忍力ひずみ履歴 


\section{5. 結語}

著者らの提案する纎維化塑性関節モデルを用いて，藤本ら ${ }^{6)} の$ 鋼立体骨組の崩壤実験および若林ら ${ }^{7)}$ の繰返し偏心水平荷重を受 ける $\mathrm{H}$ 形鋼立体骨組に対応する解析を行い， $\mathrm{H}$ 形鋼柱からなる立 体骨組が強い軸力の下で大きなねじり変形を起こす問題でも，単調 載荷繰返し載荷を問わず本解法の標準である 1 部材 4 要素近似で 実用上十分な精度を示すことを確認した。また，藤本らの骨組の柱 で測定された軸方向ひずみを本解法の定式化に用いた仮定に基づい て推定し，両者を比較することによって部材ひずみの観点からも本 モデルの導出仮定は妥当であることを示した。さらに，若林らの骨 組の柱脚断面の繊維の忘力ひずみ履歷を調べ，本解法が綝返し举動 解析においても安定であることを検証した。

参考文献

1) M.Shugyo : Elastoplastic large deflection analysis of threedimensional steel frames, J. Struct. Engrg., ASCE, Vol.129, No.9, pp.1259-1267, 2003.9

2) J. A. Stricklin, W. E. Haisler, and W. A. von Riesemann : Geometrically nonlinear structural analysis by direct stiffness method, J. Struct. Div., ASCE, Vol.97, No.9, pp.2299-2314, 1971.9

3）修行 稳, 李 剣平: コンクリート充填円形鋼管柱の非線形解析法 に関する研究，日本建築学会構造系論文集，No.505，pp.147-152， 1998.3
4) 上谷宏二，桝井 健：継り返し曲げを受ける片持梁一柱の構面内举 動限界解析法, 日本建築学会構造系論文集, No.513, pp.97-104, 1998.11

5）李 剣平, 修行 稔: 構面外水平荷重の下で繰返し水平力を受ける 円形鋼管柱の構面外累積变形に関する実験的研究，構造工学論文集， Vol.46B, pp.673-681，2000.3

6) 藤本盛久，松本芳紀：H 形断面部材より成る立体骨組の弹塑性解析に 関する研究一その 2, 日本建築学会論文報告集, No.187, pp.51-58, 1971.9

7）若林 實，中村 武，井上 明：水平力を受ける鉄骨立体骨組の弾 塑性性状に関する実験的研究, 京都大学防災研究所年報, 第 19 号 B, pp.105-128, 1976.4

8）修行 稔, 鳥津 勝: 半剛接要素を境界条件の導入に利用した I 形 鋼曲がりはりの崩壊解析，日本建築学会構造系論文集，No.566 号， pp.59-64, 2003.4

9）金尾（奥洲）例織，森迫清贵，中村 武：一軸材料線要素からなる梁 一柱有限要素を用いた銅立体ラーメンの弹塑性举動の解析，日本建 筑学会構造系論文集，No.533，pp.99-106，2000.7

10) Y. - L. Pi, M. A. Bradford, and N. S. Trahair : Inelastic analysis and behavior of steel I-beams curved in plan, J. Struct. lingrg., ASCE, Vol.126, No.7, pp.772-779, 2000.7

11）前归幸雄，林 正：文体骨組構造物の有限変仿解析，士朴学会論文 報售集，第253 号，pp.13-27，1976.9 